\title{
The Effect of Workplace Spirituality on Innovative Work Behavior
}

\author{
Vimansha R. Ranasinghe ${ }^{1}$, Samantha M. Samarasinghe ${ }^{2}$ \\ ${ }^{1}$ Department of Human Resource Management, Faculty of Commerce and Management Studies, University of \\ Kelaniya, Sri Lanka \\ ${ }^{2}$ Department of Information Technology, Faculty of Management Studies and Commerce, University of Sri \\ Jayawardenepura, Sri Lanaka \\ Correspondence: Vimansha Rangani Ranasinghe, Faculty of Commerce and Management Studies, University of \\ Kelaniya, Kelaniya, Sri Lanka.
}

Received: October 1, 2019

Accepted: October 28, $2019 \quad$ Online Published: November 8, 2019

doi:10.5539/ibr.v12n12p29

URL: https://doi.org/10.5539/ibr.v12n12p29

\begin{abstract}
Workplace spirituality is a novel concept and it has been identified as a unique way to improve organizational performance. On the other hand, many organizations are experiencing undesirable consequences of lack of workplace spirituality, such as employee stress, turnover, absenteeism, and lack of employee creativity. Hence, organizations are now focusing on developing workplace spirituality in the workplaces as it offers many advantages to organizations. Despite the growing interest on workplace spirituality, there is still a dearth of research on the topic of workplace spirituality. Literature suggests that employee innovative work behavior directly leads to enhance organizational performance and workplace spirituality leads to increase innovativeness and creativity of employees. Hence, the purpose of this paper is to fill the gap in literature, to a certain extent by proposing a conceptual model to examine the effect of workplace spirituality on employee innovative work behavior. Thus, it proposed that there is a positive effect of workplace spirituality on employee innovative work behavior. Consequently, intrinsic motivation from componential theory of creativity was integrated to identify the mediating effect of intrinsic motivation on the effect of workplace spirituality on innovative work behavior.
\end{abstract}

Keywords: workplace spirituality, innovative work behavior, intrinsic motivation

\section{Introduction}

Employee innovative work behavior is essential for long-term survival of organizations (Afsar \& Rehman, 2015; Oldham \& Cumming, 1996) as innovative work behavior is essential for achieving competitive advantage over their competitors (Aravamudhan \& Krishnaveni, 2014). Innovative work behavior of employees has taken a burgeoning interest of employers in organizations due to highly dynamic economic environment, globalization, ever changing customer wants in the business environment and rapid change in the market (Akram, Lei \& Haider, 2016; Tajeddini \& Trueman, 2008). According to Afsar and Rehman (2015) spirituality of an individual's mindset encourage or motivate creativity and innovativeness within a person and it directly affects organizational productivity. Moreover, workplace spirituality brings happiness and joyfulness to the employee and it provides a meaningful working environment for the employees (Milliman, Czaplewski \& Ferguson, 2003). Today, organizations are experiencing negative consequences of lack of workplace spirituality, such as employee stress, turnover, and absenteeism which reduces organizational performance (Ashmos \& Duchon, 2000; Hassan, Bin Nadeem, \& Akhter, 2016).

Previous studies revealed that workplace spirituality positively related with employee work attitudes (Neck \& Milliman, 1994), employee engagement (Roof, 2015; Saks, 2011), organizational citizenship behavior (Saks, 2006), intrinsic work satisfaction (Milliman et al, 2003), trust and personal fulfillment (Krishnakumar \& Neck, 2002), and job satisfaction (Lee, Lovelace, \& Manz, 2014; Mydin, Kanesan, \& Pitchay, 2018; Milliman, et al., 2003). Further, workplace spirituality increase the productivity of the organization (Fry \& Matherly, 2006), innovation and creativity of the employees, and employee performance (Giacalone \& Jurkiewicz, 2003; Jurkiewicz \& Giacalone, 2004). Fry (2003) identified that workplace spirituality encourages employee to play extra role or pro-social behavior, develop unity within the organization, reduce absenteeism, reduce turnover (Milliman et al., 2003; Gatling, Kim, \& Milliman, 2016) and decrease employee deviant behavior (Ahmad \& Omar, 2014). Lee et al. (2014) examined the relationship between workplace spirituality and the ethical climate 
and identified a significant positive relationship between workplace spirituality and ethical climate. Workplace spirituality has a positive impact on decision-making, problem solving capabilities, and greater creativity (Weitz, Vardi, \& Setter, 2012). Ahmadi, Nami, and Barvarz (2014) posited that workplace spirituality is not related to any particular religion or religious system. Moreover, prior studies found that valuing the work is a vital driving force to be intrinsically motivate the employee (Fry, 2003; Urdan \& Maehr, 1995).

Though the organizational leaders have understood the importance of innovative work behavior of employees and workplace spirituality (De Jong \& Den Hartog, 2007; Gupta, Kumar, \& Singh, 2014; Rego \& Pina e Cunha, 2008; Saks, 2011), it was not sufficiently studied (Afsar \& Rehman, 2015; Duchon \& Plowman, 2005; Jurkiewicz \& Giacalone, 2004). Burgeoning interest on workplace spirituality has led to develop different theories and empirical work on workplace spirituality and its outcomes (Kolodinsky, Giacalone, \& Jurkiewicz, 2008; Pawar, 2009). However, dearth of research on the topic of workplace spirituality was highlighted (Gatling et al., 2016; Pawer, 2014; Sheep, 2006) especially in the Eastern world (Petchsawang \& Duchon, 2009). Besides, human beings are not only rational but also emotional and spiritual (Rego \& Pina e Cunha, 2008). Hence, the objective of the current study was to examine the effect of workplace spirituality on the innovative work behavior of employees. Further, intrinsic motivation from componential theory of creativity was integrated to the model to identify the mediating effect of intrinsic motivation on the effect of workplace spirituality on innovative work behavior.

To align with the objective of the study, this paper hypothesized a conceptual model for workplace spirituality and employee innovative work behavior. The conceptual model was developed based on the literature related to the innovative work behavior (as the dependent variable) and workplace spirituality (as the independent variable) Employees show creative working behavior when their work is meaningful (Afsar \& Rehman, 2015). Moreover, intrinsic task motivation is one of the components that enhance individual's creative behavior (Amabile, 2012; Vinarski-Peretz \& Carmeli, 2011). Besides, there is a significant positive effect of workplace spirituality on intrinsic motivation (Chalofsky \& Krishna, 2009; Fry, 2003; Urdan \& Maehr, 1995). Hence, the proposed conceptual model suggests that intrinsic motivation mediates the effect of workplace spirituality on the innovative work behavior of employees.

The rest of the paper is organized as follows. Section 2 presents the review of literature concerning workplace spirituality and innovative work behavior of employees. Next, in Section 3, formulation of hypotheses and the development of the conceptual model is discussed. Section 4 presents the theoretical framework and methodology of this study is given in Section 5. Then, the implications of this study and directions for future research are presented in Section 6. Finally, the conclusion of the study is given in Section 7.

\section{Literature Review}

\subsection{Workplace Spirituality}

Workplace spirituality refers to "the recognition that employees have an inner life that nourishes and is nourished by meaning work that takes place in the context of community (Ashmos \& Duchon, 2000, p.137). Belwalkar, Vohra, and Pandey (2018) defined workplace spirituality as the experience which people undergoing when seeking meaning in their work and desire to connect with other human beings. According to Harrington (2004, p.33) "spirituality is employees' sharing and experiencing some common attachments and attractions with each other within the workplace." Pawar (2009) explained spirituality as the employee experience that includes sense of meaning, community, and transcendence Kolodinsky et al. (2008) referred organizational spirituality as employee attitudes towards higher order values and promoting those values to realize collective interest through fulfilling an individual's interests.

According to Mousa and Alas (2016), the concept of workplace spirituality has become a buzzword in contemporary organizations. Further, organizations consist of group of people and the spiritual needs of individuals should fulfill accordingly (Krishnalumar \& Neck, 2002). Otherwise, individuals become dissatisfied and organizational spirituality becomes low. Bringing employees' heart, soul, mind, and body into one place is very much important for both individual and organizational success (Mousa \& Alas, 2016).

Workplace spirituality consists of individual experience with his/her inner feelings (Kinjerski \& Skrypnek, 2004) and his/her workplace environment (Jurkiewicz \& Giacalone, 2004). Workplace spirituality is not about specific religion or converting people to a particular religious' system (Ashmos \& Duchon, 2000; Afsar \& Rehman, 2015; Pourmola, Bagheri, Alinezhad, \& Nejad, 2019). According to Fagley and Adler (2012), through workplace spirituality, employees can find out their ultimate purpose of life. Thus, it leads to develop connectedness with peers and others related to the working environment. Workplace spirituality includes tolerance, feeling of interconnectivity, acceptability of the norms in organizations (Afsar \& Rehman, 2015), kindness, empathy, and 
trust (Hassan, Bin Nadeem \& Akhter, 2016). According to the review of literature much of the studies defined workplace spirituality at individual level (Ashmos \& Duchon, 2000; Duchon \& Plowman, 2005; Milliman et al., 2003) and some other studies have defined workplace spirituality at organizational level (Jurkiewicz \& Giacalone, 2004; Kolodinsky et al., 2003).

Now a days most of the people are more spiritual not only in their personal life but also in their working life (Neck \& Milliman, 1994). The benefits of workplace spirituality can be categorized under three levels; individual-level, organizational level and societal level (Faro Albuquerque, Campos Cunha, Dias Martins, \& Brito Sá, 2014). Individual level benefits include the mental and physical fitness of employees, dramatic increase in personal growth and self-worth (Krahnke, Giacalone, \& Jurkiewicz, 2003), and realization of employee full potential (Mitroff \& Dentor, 1999). Workplace spirituality leads to an increase in work productivity because it creates an enjoyable working experience in the workplace (Janfeshan, Panahy, Veiseh, \& Kamari, 2011). According to Neck and Milliman (1994) organizations focusing on spiritual values tend to provide more opportunities to employees for their personal growth and development. Furthermore, it was observed that workplace spirituality leads to increase feeling toward others and it acts as a weapon that attracts and retain employees within the organization (Giacalone \& Jurkiewicz, 2003; Jena \& Pradhan, 2018). Enhancing trust among people (Neck \& Milliman, 1994) and increasing interconnectedness (Daniel, 2015) create a more motivated organizational working environment as benefits of workplace spirituality. Workplace spirituality is very much important not only because it leads to enhance personal growth but also to increase the psychological contract between employers and employees (Ahiauzu \& Asawo, 2012). Simply, the goals of the spirituality are to reach a higher personal potential that leads to greater employee creativity, commitment, and motivation (OsmanGani, Hashim, \& Ismail, 2013). Pandey, Gupta, and Arora (2009) identified workplace spirituality as an employee friendly working environment which mainly focuses on employee spirit. Moreover, Fairholm (1996) identified organizations as spiritual entities because employees spend more hours at the workplace. According to Brown (2003) organizational spirituality leads to improve integrity, introduce ethics to the workplace, motivate emotional competencies, and establish specific groups in the workplace and empowering the workforce.

Different scholars see workplace spirituality as a multi-faceted construct (Hussain \& Sharma, 2012; Singh \& Mishra, 2016). There are six dimensions of workplace spirituality, namely, 1) inner life 2) meaning and purpose in work 3) a sense of connection and community 4) block of spirituality 5) personal responsibility and 6) positive connection with other individual and contemplation (Ashmos \& Duchon, 2000). However, Milliman et al. (2003) did some modifications to these dimensions and introduced three new dimensions that mainly focus on motivation and psychology. Meaningful at work focus on individual level was the first dimension (Janfeshan et al., 2011). The sense of community was the second dimension focusing on the community level. The third dimension was organizational values which aligned with the organizational level. Some scholars categorized workplace spirituality into three camps based on the definitions, such as individual experience and organizational facilitation and a mix of both (Petchsawang \& McLean, 2017). According to Burack (1999) workplace spirituality has three main components, namely internal, external and integrated.

\subsection{Intrinsic Motivation}

Intrinsic motivation refers to the degree of interest or enjoyment that an individual is experiencing when performing a work task without being controlled by external factors (Saeed, Afsar, Shahjehan, \& Shah, 2019). According to Legault (2016), intrinsic motivation refers to engaging in the behavior that is inherently enjoyable and intrinsically motivated action that is not separable from the behavior. For instance, children play outdoor games (such as running, jumping) not for any reason just because of their fun and internal satisfaction. Ryan and Deci (2000) found that enjoyment and psychological well-being as some benefits of intrinsic motivation. Nevertheless, the social environment should play an important role to flourish the intrinsic motivation and this can be done by influencing perceived autonomy and competence. For an example, when supervisors give positive feedback to their employees, intrinsic motivation of those employees rises. However, to have more fruitful results employees should have autonomy and feel competent in performing the action.

Componential theory of creativity (Amabile, 2013) identified three components of creativity namely domain relevant skills, creativity relevant process, and task motivation. According to Amabile, intrinsic motivation involves activity of interest, enjoyment and personal sense of challenge and this is only not sufficient to get favorable creative outcomes (Vinarski-Peretz \& Carmeli, 2011). Intrinsic motivation is an important condition for innovative work behavior because it influence employee's cognition, behavior and emotions and directly affect their performance (Saeed, Afsar, Shahjehan, \& Shah, 2019; Zhou \& George, 2003). When employee behavior is controlled by intrinsic motivation, his/her actions become more stabilize and his/her performance goes up. According to Jaussi and Dionne (2003) employee creative performance increase when they are 
intrinsically motivated. Saeed, Afsar, Shahjehan, and Shah (2019) also highlighted that intrinsic motivators are bound up with the work itself.

\subsection{Innovative Work Behavior}

Innovative work behavior is considered as a very important tool that leads to gain competitive advantage over competitors in this knowledge-driven economy as no organization can survive without having continuous innovation (Mayfield \& Mayfield, 2014). Innovative work behavior refers to deliberately introducing new ideas and implement those ideas with the behavior modification to increase organizational as well as employee's performance (De Jong \& Den Hartog, 2007). Employee creativity and innovative work behavior are two different concepts. Innovative work behavior focusses on discovery, recognition, generation, development, modification, adaption and implementation of ideas (King \& Anderson, 2002; Scott \& Bruce, 1994) while creativity involved with novel, new and useful ideas (Scott \& Bruce, 1994). According to Singh and Sarkar (2019) innovative work behavior means the employee's ability to find new ideas, promote them and to implement new ideas.

Innovative work behavior consists of three steps namely idea generation, idea promotion, and idea realization (Rahman, Osman-Gani, Momen, \& Islam, 2015). Idea generation happens when employees produce new ideas, whereas idea promotion means finding supporters surrounding the ideas and idea realization involves producing a prototype, which can test by individuals or organizations (Rahman, Osman-Gani, Momen, \& Islam, 2015). Moreover, De Jong and Den Hartog (2010) introduced another step as idea implementation that transform creative ideas into innovative ideas. There are many benefits of innovative work behavior including increasing work engagement, declining work-life conflicts (Abstein, Heidenreich, \& Spieth, 2014), and increasing organizational effectiveness (Basadur, 2004). Most of the organizations use employee innovation ideas as building blocks to produce new products or services in their organizations (De Jong \& Den Hartog, 2007).

Previous study findings have indicated employee innovative work behavior highly dependent on their relationship with their peers, subordinates, supervisors and the clients (Anderson, De Dreu, \& Nijstad, 2004). Moreover, employees are able to enhance their business performance through their ability to create and translate their ideas to successful business outcomes (Pradhan \& Jena, 2019). The importance of innovative work behavior of employees has encouraged researchers to examine the impact of different factors such as personality types, leadership styles, and working environment on innovative work behavior (Pelz \& Andrews, 1966). Moreover, a plethora of studies revealed that there is a positive impact of transformational leadership on employee innovative behavior (Afsar, Badir, \& Bin Saeed, 2014). Some scholars have examined the relationship between innovative work behavior and organizational resources (Spreitzer, 1995; Madjar, 2008), climate for innovation (Scott \& Bruce, 1994), personality (George \& Zhou, 2001), self-efficacy (Axtell, Holman, Unsworth, Wall, Waterson, \& Harrington, 2000), problem solving skills (Scott \& Bruce, 1994), transformational leadership (Masood \& Afsar, 2017; Pieterse, Knippenberg, Schippers, \& Stam, 2009). However, the review of literature highlighted that workplace spirituality is not sufficiently studied (Afsar \& Rehman, 2015; Duchon \& Plowman, 2005; Jurkiewicz \& Giacalone, 2004). Even though there is a burgeoning interest on workplace spirituality (Kolodinsky, Giacalone, \& Jurkiewicz, 2008; Pawar, 2009), little research has been carried out on the topic of workplace spirituality (Gatling et al., 2016; Pawer, 2014; Sheep, 2006). Hence, by developing a conceptual model and by statistically validating the model, researcher contribute to fill the gap of workplace spirituality literature to a certain extent.

\section{Hypotheses of the Study}

\subsection{Workplace Spirituality and Innovative Work Behavior}

Most of the prior research focused on the benefits of workplace spirituality (Quatro, 2004). It was found that workplace spirituality positively affects organizational performance (Quatro, 2002), profitability (Duchan \& Plowman, 2005), organizational commitment (Fry, Vitucci, \& Cedillo, 2005), job involvement and organizational based self-esteem (Milliman et al., 2003). According to Milliman et al. (2003), meaningful work is expected to be related to individual attitudes towards the organization. Employees exhibit creative behavior (Jung, Chow, \& Wu, 2003), discretionary behavior such as innovative work behavior (Pierce, Gardner, Cummings, \& Dunham, 1989), and they try to do changes in the work place accepting challenges (Afsar \& Rehman, 2015) when they find meaning in work. Moreover, employees try to understand the problems in a way that is more rigorous and try to search for more solutions when they perceive that their work roles are important in the organization, (Gilson \& Shalley, 2004). Besides, some other research posited that workplace spirituality assist achieving sense of purpose, encourage creativity, and in turn leads to motivate innovative work behavior (Pawar, 2009; Gupta et al. 2014; Afsar \& Rehman 2015). Based on the above justification, hypothesis one $\left(\mathrm{H}_{1}\right)$ is 
proposed:

$\mathrm{H}_{1}$ : Workplace spirituality has a significant positive effect on innovative work behavior.

3.2 Mediating Role of Intrinsic Motivation on the Relationship Between Workplace Spirituality and Innovative Work Behavior

Intrinsic motivation refers to the will and energy that leads to the behavior or the interest and the pleasure or satisfaction that employee gets when he/she engaged in an activity (Saeed et al., 2019). According to Saeed et al. intrinsic motivation affects employee's emotions, behavior, and cognition. Accordingly, it leads to enhance more stable and better performance. When an employee intrinsically attracts to an activity, he/she is focused on it and tries to do experiments with it and this leads to having more creative behavior (Jaussi \& Dionne, 2003). Intrinsic motivation is one of the components in the componential theory of creativity which leads to uplift the individual's creative behavior. Further, when employees try to find out the final meaning and the purpose of his/her work, it motivates employees to do differences within the working environment (Afsar \& Rehman, 2015). The link between meaning at work [workplace spirituality] and intrinsic work motivation was established in very early research as well (Hackman \& Oldham, 1976). Well-established self-determination theory also highlighted that employee freedom, competence, and relatedness in their work activities leads to intrinsic motivation (Ryan \& Deci, 2000) When employees think their task as interesting and meaningful, they engage with it in a psychological freedom that enhance intrinsic motivation (Steger, Dik, \& Duffy, 2012; Hackman \& Oldham, 1976). Workplace spirituality leads to share power, trust and flexibility which leads to improve intrinsic motivation (Afsar, Badir, \& Kiani, 2016; Chalofsky \& Krishna, 2009). Based on the above justification, hypothesis two $\left(\mathrm{H}_{2}\right)$, hypothesis three $\left(\mathrm{H}_{3}\right)$, and hypothesis four $\left(\mathrm{H}_{4}\right)$ are proposed:

$\mathrm{H}_{2}$ : Workplace spirituality has a significant positive effect on intrinsic motivation.

$\mathrm{H}_{3}$ : Intrinsic motivation has a significant positive effect on innovative work behavior

$\mathrm{H}_{4}$ : When intrinsic motivation is high, workplace spirituality has a stronger effect on innovative work behavior.

\section{Theoretical Framework}

Based on the comprehensive review of literature, it was clear that there is an impact of workplace spirituality on innovative working behavior. When workplace spirituality level increases, the innovative working behavior also increases. In addition, workplace spirituality has an impact on intrinsic motivation and intrinsic motivation has an impact on innovative work behavior. Further, intrinsic motivation influences the relationship between workplace spirituality and innovative working behavior. Therefore, based on literature the conceptual model developed for the current study is given in Figure 1:

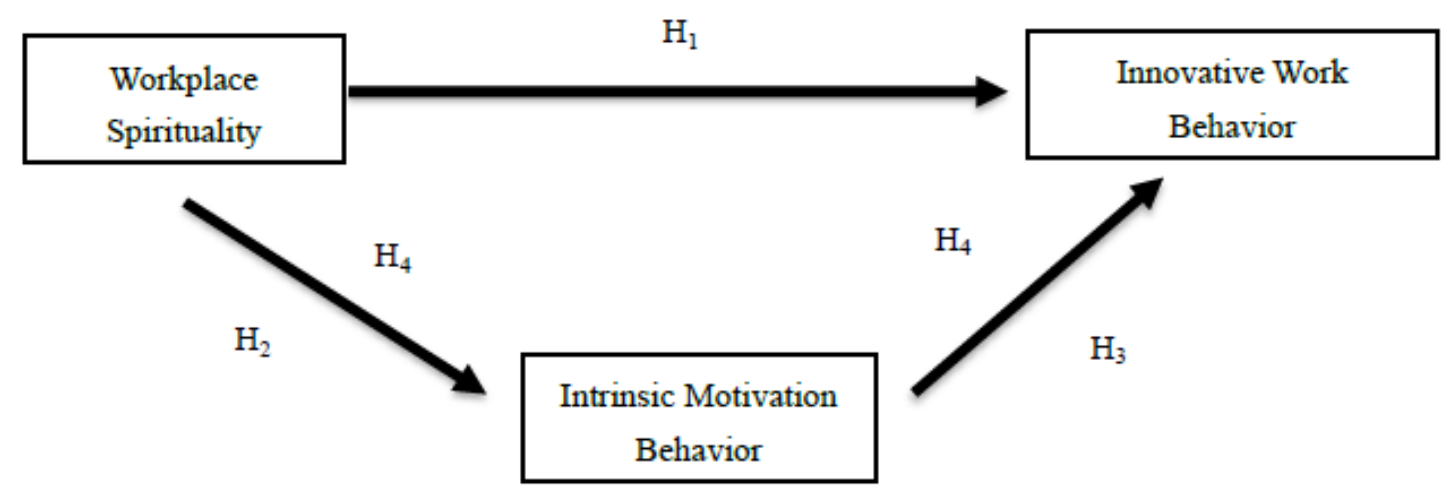

Figure 1. Conceptual model

\section{Implications and Directions for Future Research}

As the impact of workplace spirituality and innovative work behavior was not addressed to date, this study offers important implications to theory and practice. . It is very much important to identify the factors that foster innovative work behavior of employees as the human resource in an organization vary according to their culture, family and educational background (Afsar \& Rehman, 2015). Thus, this study may assist to understand the drivers of innovative work behavior among employees through workplace spirituality and intrinsic motivation. Up until to date, most of the research on spirituality at work has focused at individual level. This study is 
amongst the few studies that attempts to examine workplace spirituality at the organizational level on innovative work behavior of employees. The model developed in the current study considered only two factors; workplace spirituality and intrinsic motivation as the factors that promote innovative work behavior. Future research needs to be done to examine other factors that may have an impact on innovative work behavior.

\section{Conclusion}

The objective of this study was to develop and validate a theoretical model to understand the effect that workplace spirituality has on innovative work behavior and how intrinsic motivation influence the impact of workplace spirituality on innovative work behavior. It is theorized that when workplace spirituality is high in the organization, the innovative work behavior of employees tends to be high. Furthermore, literature argued that intrinsic motivation has an influence on the effect of workplace spirituality on innovative work behavior of employees. Thus, based on the literature the theoretical model was hypothesized. The model developed will be empirically tested in future research for its statistical validity.

\section{References}

Abstein, A., Heidenreich, S., \& Spieth, P. (2014). Innovative work behavior: The impact of comprehensive HR system perceptions and the role of work-life conflict. Industry and Innovation, 21(2), 91-116. https://doi.org/10.1080/13662716.2014.896159

Afsar, B., \& Rehman, M. (2015). The relationship between workplace spirituality and innovative work behavior: The mediating role of perceived person-organization fit. Journal of Management, Spirituality \& Religion, 12(4), 329-353. https://doi.org/10.1080/14766086.2015.1060515

Afsar, B., Badir, Y., \& Kiani, U. (2016). Linking spiritual leadership and employee pro-environmental behavior: The influence of workplace spirituality, intrinsic motivation, and environmental passion. Journal of Environmental Psychology, 45, 79-88. https://doi.org/10.1016/j.jenvp.2015.11.011

Afsar, B., F. Badir, Y., \& Bin Saeed, B. (2014). Transformational leadership and innovative work behavior. Industrial Management \& Data Systems, 114(8), 1270-1300. https://doi.org/10.1108/imds-05-2014-0152

Ahiauzu, A., \& Asawo S. P. (2012). Impact of clear and compelling vision on workers' commitment in Nigerian organizations: An examination of workplace spirituality. Journal of Leadership, Accountability and Ethics, 9(6), 113-124.

Ahmad, A., \& Omar, Z. (2014). Reducing deviant behavior through workplace spirituality and job satisfaction. Asian Social Science, 10(19). https://doi.org/10.5539/ass.v10n19p107

Ahmadi, S., Nami, Y., \& Barvarz, R. (2014). The relationship between spirituality in the workplace and organizational citizenship behavior. Procedia - Social and Behavioral Sciences, 114, 262-264. https://doi.org/10.1016/j.sbspro.2013.12.695

Akram, T., Lei, S., \& Haider, M. (2016). The impact of relational leadership on employee innovative work behavior in IT industry of China. Arab Economic and Business Journal, 11(2), 153-161. https://doi.org/10.1016/j.aebj.2016.06.001

Amabile, T. (2012). Componential Theory of Creativity (Working Paper No.12-096). Retrieved from http://hbswk.hbs.edu/

Amabile, T. (2013). Charismatic theory of leadership. Encyclopedia of Management Theory, 134-139. https://doi.org/10.4135/9781452276090.n42

Anderson, N., De Dreu, C., \& Nijstad, B. (2004). The routinization of innovation research: A constructively critical review of the state-of-the-science. Journal of Organizational Behavior, 25(2), 147-173. https://doi.org/10.1002/job.236

Aravamudhan, N., \& Krishnaveni, R. (2014). Spirituality at work: An emerging template for organization capacity building. SMS Varanasi, 7(1), 63-78.

Ashmos, D., \& Duchon, D. (2000). Spirituality at work. Journal of Management Inquiry, 9(2), 134-145. https://doi.org/10.1177/105649260092008

Axtell, C., Holman, D., Unsworth, K., Wall, T., Waterson, P., \& Harrington, E. (2000). Shop floor innovation: Facilitating the suggestion and implementation of ideas. Journal of Occupational and Organizational Psychology, 73(3), 265-285. https://doi.org/10.1348/096317900167029

Basadur, M. (2004). Leading others to think innovatively together: Creative leadership. The Leadership 
Quarterly, 15(1), 103-121. https://doi.org/10.1016/j.leaqua.2003.12.007

Belwalkar, S., Vohra, V., \& Pandey, A. (2018). The relationship between workplace spirituality, job satisfaction and organizational citizenship behaviors - an empirical study. Social Responsibility Journal, 14(2), 410-430. https://doi.org/10.1108/srj-05-2016-0096

Brown, R. (2003). Organizational spirituality: The sceptic's version. Organization, 10(2), 393-400. https://doi.org/ 10.1177/1350508403010002013

Burack, E. (1999). Spirituality in the workplace. Journal of Organizational Change Management, 12(4), 280-292. https://doi.org/10.1108/09534819910282126

Chalofsky, N., \& Krishna, V. (2009). Meaningfulness, commitment, and engagement: the intersection of a deeper level of intrinsic motivation. Advances in Developing Human Resources, 11(2), 189-203. https://doi.org/10.1177/1523422309333147

Daniel, J. (2015). Workplace spirituality and stress: evidence from Mexico and US. Management Research Review, 38(1), 29-43. https://doi.org/10.1108/mrr-07-2013-0169

De Jong, J., \& Den Hartog, D. (2007). How leaders influence employees' innovative work behavior. European Journal of Innovation Management, 10(1), 41-64. https://doi.org/10.1108/14601060710720546

De Jong, J., \& Den Hartog, D. (2010). Measuring innovative work behavior. Creativity and Innovation Management, 19(1), 23-36. https://doi.org/10.1111/j.1467-8691.2010.00547.x

Duchon, D., \& Plowman, D. (2005). Nurturing the spirit at work: Impact on work unit performance. The Leadership Quarterly, 16(5), 807-833. https://doi.org/10.1016/j.leaqua.2005.07.008

Fagley, N., \& Adler, M. (2012). Appreciation: A spiritual path to finding value and meaning in the workplace. Journal of Management, Spirituality \& Religion, 9(2), 167-187. https://doi.org/10.1080/14766086.2012.688621

Fairholm, G. (1996). Spiritual leadership: Fulfilling whole-self needs at work. Leadership \& Organization Development Journal, 17(5), 11-17. https://doi.org/10.1108/01437739610127469

Faro Albuquerque, I., Campos Cunha, R., Dias Martins, L., \& Brito Sá, A. (2014). Primary health care services: workplace spirituality and organizational performance. Journal of Organizational Change Management, 27(1), 59-82. https://doi.org/10.1108/jocm-11-2012-0186

Fry, L. (2003). Toward a theory of spiritual leadership. The Leadership Quarterly, 14(6), 693-727. https://doi.org/10.1016/j.leaqua.2003.09.001

Fry, L. W., \& Matherly, L. L. (2006). Spiritual leadership and organizational performance. Paper Presented at the Academy of Management, Atlanta. Retrieved from https://pdfs.semanticscholar.org/f354/43471925684026e5bedf3881c8b511e5b5ab.pdf

Fry, L., Vitucci, S., \& Cedillo, M. (2005). Spiritual leadership and army transformation: Theory, measurement, and establishing a baseline. The Leadership Quarterly, 16(5), 835-862. https://doi.org/10.1016/j.leaqua.2005.07.012

Gatling, A., Kim, J., \& Milliman, J. (2016). The relationship between workplace spirituality and hospitality supervisors' work attitudes. International Journal of Contemporary Hospitality Management, 28(3), 471-489. https://doi.org/10.1108/ijchm-08-2014-0404

George, J., \& Zhou, J. (2001). When openness to experience and conscientiousness are related to creative behavior: An interactional approach. Journal of Applied Psychology, 86(3), 513-524.

https://doi.org/10.1037//0021-9010.86.3.513

Giacalone, R., \& Jurkiewicz, C. (2003). The Handbook of Workplace Spirituality and Organizational Performance (pp. 3-28). Armonk, NY: M.E. Sharpe.

Gilson, L., \& Shalley, C. (2004). A little creativity goes a long way: An examination of teams' engagement in creative processes. Journal of Management, 30(4), 453-470. https://doi.org/10.1016/j.jm.2003.07.001

Gupta, M., Kumar, V., \& Singh, M. (2014). Creating satisfied employees through workplace spirituality: A study of the private insurance sector in Punjab (India). Journal of Business Ethics, 122(1), 79-88. https://doi.org/10.1007/s10551-013-1756-5

Hackman, J., \& Oldham, G. (1976). Motivation through the design of work: test of a theory. Organizational Behavior and Human Performance, 16(2), 250-279. https://doi.org/10.1016/0030-5073(76)90016-7 
Harrington, W. (2004). Worldwide resiliency of business degree graduate students: An examination of spiritual experiences and psychological attitudes. Association of employment practices and principals. Retrieved from http://www.aepp.net/documents/aepp_proceedings_2004_final.pdf

Hassan, M., Bin Nadeem, A., \& Akhter, A. (2016). Impact of workplace spirituality on job satisfaction: Mediating effect of trust. Cogent Business \& Management, 3(1). https://doi.org/10.1080/23311975.2016.1189808

Hussain, A., \& Sharma, M. (2012). Workplace spirituality and engagement among employees in public and private sector organization. International Journal of Social and Allied Research, 1(1), 5-9.

Janfeshan, K., Panahy, B., Veiseh, S., \& Kamari, F. (2011). Spirituality in the work place and its impacts on the efficiency of management. 2nd International Conference on Business and Economic Research (2nd ICBER 2011).

Jaussi, K., \& Dionne, S. (2003). Leading for creativity: The role of unconventional leader behavior. The Leadership Quarterly, 14(4-5), 475-498. https://doi.org/10.1016/s1048-9843(03)00048-1

Jena, L., \& Pradhan, S. (2018). Workplace persuasion: Conceptual model, development and validation. Global Business Review. https://doi.org/10.1177/0972150918761086

Jung, D., Chow, C., \& Wu, A. (2003). The role of transformational leadership in enhancing organizational innovation: Hypotheses and some preliminary findings. The Leadership Quarterly, 14(4-5), 525-544. https://doi.org/10.1016/s1048-9843(03)00050-x

Jurkiewicz, C., \& Giacalone, R. (2004). A values framework for measuring the impact of workplace spirituality on organizational performance. Journal of Business Ethics, 49(2), 129-142. https://doi.org/10.1023/b:busi.0000015843.22195.b9

King, N., \& Anderson, N. (2002). Managing innovation and change: a critical guide for organizations. Andover, UK: Cengage Learning EMEA.

Kinjerski, V., \& Skrypnek, B. (2004). Defining spirit at work: Finding common ground. Journal of Organizational Change Management, 17(1), 26-42. https://doi.org/10.1108/09534810410511288

Kolodinsky, R., Giacalone, R., \& Jurkiewicz, C. (2008). Workplace values and outcomes: Exploring personal, organizational, and interactive workplace spirituality. Journal of Business Ethics, 81(2), 465-480. https://doi.org/10.1007/s10551-007-9507-0

Krahnke, K., Giacalone, R., \& Jurkiewicz, C. (2003). Point-counterpoint: Measuring workplace spirituality. Journal of Organizational Change Management, 16(4), 396-405. https://doi.org/10.1108/09534810310484154

Krishnakumar, S., \& Neck, C. (2002). The "what", "why" and "how" of spirituality in the workplace. Journal of Managerial Psychology, 17(3), 153-164. https://doi.org/10.1108/02683940210423060

Lee, S., Lovelace, K., \& Manz, C. (2014). Serving with spirit: An integrative model of workplace spirituality within service organizations. Journal of Management, Spirituality \& Religion, 11(1), 45-64. https://doi.org/10.1080/14766086.2013.801023

Legault, L. (2016). Intrinsic and Extrinsic motivation. Encyclopedia of Personality and Individual Differences, 1-4. https://doi.org/10.1007/978-3-319-28099-8_1139-1

Madjar, N. (2008). Emotional and informational support from different sources and employee creativity. Journal of Occupational and Organizational Psychology, 81(1), 83-100. https://doi.org/10.1348/096317907x202464

Masood, M., \& Afsar, B. (2017). Transformational leadership and innovative work behavior among nursing staff. Nursing Inquiry, 24(4), e12188. https://doi.org/10.1111/nin.12188

Mayfield, J., \& Mayfield, M. (2004). The effects of leader communication on worker in- novation. American Business Review, 6, 46-51.

Milliman, J., Czaplewski, A., \& Ferguson, J. (2003). Workplace spirituality and employee work attitudes. Journal of Organizational Change Management, 16(4), 426-447. https://doi.org/10.1108/09534810310484172

Mitroff, I., \& Denton, E. (1999). A spiritual audit of corporate America: A hard look at spirituality, religion, and values in the workplace. San Francisco: CA: Jossey-Bass.

Mousa, M., \& Alas, R. (2016). Workplace spirituality and organizational commitment: A study on the public 
schools teachers in Menoufia (Egypt). African Journal of Business Management, 10(10), 247-255. https://doi.org/ 10.5897/ajbm2016.8031

Mydin, A., Kanesan, A., \& Pitchay, A. (2018). Workplace spirituality enhance organizational commitment in the school management. Asian Journal of Public Administration and Law, Asian Economic and Social Society, $1(1), 1-8$.

Neck, C., \& Milliman, J. (1994). Thought Self-leadership. Journal of Managerial Psychology, 9(6), 9-16. https://doi.org/10.1108/02683949410070151

Oldham, G., \& Cummings, A. (1996). Employee creativity: Personal and contextual factors at work. Academy of Management Journal, 39(3), 607-634. https://doi.org/10.2307/256657

Osman-Gani, A., Hashim, J., \& Ismail, Y. (2013). Establishing linkages between religiosity and spirituality on employee performance. Employee Relations, 35(4), 360-376. https://doi.org/10.1108/er-04-2012-0030

Otaye-Ebede, L., Shaffakat, S., \& Foster, S. (2019). A multilevel model examining the relationships between workplace spirituality, ethical climate and outcomes: A social cognitive theory perspective. Journal of Business Ethics. https://doi.org/10.1007/s10551-019-04133-8

Pandey, A., Gupta, R., \& Arora, A. (2009). Spiritual climate of business organizations and its impact on customers' experience. Journal of Business Ethics, 88(2), 313-332.

https://doi.org/10.1007/s10551-008-9965-z

Pawar, B. (2009). Workplace spirituality facilitation: A comprehensive model. Journal of Business Ethics, 90(3), 375-386. https://doi.org/10.1007/s10551-009-0047-7

Pawar, B. (2014). Leadership spiritual behaviors toward subordinates: an empirical examination of the effects of a leader's individual spirituality and organizational spirituality. Journal of Business Ethics, 122(3), 439-452. https://doi.org/10.1007/s10551-013-1772-5

Pelz, D., \& Andrews, F. (1996). Scientists in organization: Productive climate for research and development. New York: Wiley.

Petchsawang, P., \& Duchon, D. (2009). Measuring workplace spirituality in an Asian context. Human Resource Development International, 12(4), 459-468. https://doi.org/10.1080/13678860903135912

Petchsawang, P., \& McLean, G. (2017). Workplace spirituality, mindfulness meditation, and work engagement. Journal of Management, Spirituality \& Religion, 14(3), 216-244. https://doi.org/10.1080/14766086.2017.1291360

Pierce, J., Gardner, D., Cummings, L., \& Dunham, R. (1989). Organization-based self-esteem: construct definition, measurement, and validation. Academy of Management Journal, 32(3), 622-648. https://doi.org/10.2307/256437

Pieterse, A., van Knippenberg, D., Schippers, M., \& Stam, D. (2009). Transformational and transactional leadership and innovative work behavior: The moderating role of psychological empowerment. Journal of Organizational Behavior, 31(4), 609-623. https://doi.org/10.1002/job.650

Pourmola, M., Bagheri, M., Alinezhad, P., \& Peyravi Nejad, Z. (2019). Investigating the impact of organizational spirituality on human resources productivity in manufacturing organizations. Management Science Letters, 121-132. https://doi.org/10.5267/j.msl.2018.10.011

Pradhan, S., \& Jena, L. (2019). Does meaningful work explains the relationship between transformational leadership and innovative work behavior. Vikalpa: The Journal for Decision Makers, 44(1), 30-40. https://doi.org/10.1177/0256090919832434

Quatro, S. (2002). Organizational spiritual normativity as an influence on organizational culture and performance in Fortune 500 firms. Iowa State University Digital Repository.

Quatro, S. (2004). New age or age old: Classical management theory and traditional organized religion as underpinnings of the contemporary organizational spirituality movement. Human Resource Development Review, 3(3), 228-249. https://doi.org/10.1177/1534484304267830

Rahman, M., Osman-Gani, A., Momen, M., \& Islam, N. (2015). Testing knowledge sharing effectiveness: Trust, motivation, leadership style, workplace spirituality and social network embedded model. Management \& Marketing, 10(4), 284-303. https://doi.org/10.1515/mmcks-2015-0019

Rego, A., \& Pina e Cunha, M. (2008). Workplace spirituality and organizational commitment: an empirical study. 
Journal of Organizational Change Management, 21(1), 53-75. https://doi.org/10.1108/09534810810847039

Roof, R. (2015). The association of individual spirituality on employee engagement: The spirit at work. Journal of Business Ethics, 130(3), 585-599. https://doi.org/10.1007/s10551-014-2246-0

Ryan, R., \& Deci, E. (2000). Intrinsic and Extrinsic motivations: Classic definitions and new directions. Contemporary Educational Psychology, 25(1), 54-67. https://doi.org/10.1006/ceps.1999.1020

Saeed, B., Afsar, B., Shahjehan, A., \& Shah, S. (2019). Does transformational leadership foster innovative work behavior? The roles of psychological empowerment, intrinsic motivation, and creative process engagement. Economic Research, 32(1), 254-281.

Saks, A. (2006). Antecedents and consequences of employee engagement. Journal of Managerial Psychology, 21(7), 600-619. https://doi.org/10.1108/02683940610690169

Saks, A. (2011). Workplace spirituality and employee engagement. Journal of Management, Spirituality \& Religion, 8(4), 317-340. https://doi.org/10.1080/14766086.2011.630170

Scott, S., \& Bruce, R. (1994). Determinants of innovative work behavior: A path model of individual innovation in the workplace. Academy of Management Journal, 37(3), 580-607. https://doi.org/10.2307/256701

Sheep, M. (2006). Nurturing the whole person: The ethics of workplace spirituality in a society of organizations. Journal of Business Ethics, 66(4), 357-375. https://doi.org/10.1007/s10551-006-0014-5

Singh, M., \& Sarkar, A. (2019). Role of psychological empowerment in the relationship between structural empowerment and innovative work behavior. Management Research Review, 42(4), 521-538. https://doi.org/10.1108/mrr-04-2018-0158

Singh, S., \& Mishra, P. (2016). A review on role of spirituality at workplace. The International Journal of Indian Psychology, 3(3), 141-146.

Spreitzer, G. (1995). Psychological empowerment in the workplace: Dimensions, measurement, and validation. Academy of Management Journal, 38(5), 1442-1465. https://doi.org/10.5465/256865

Steger, M., Dik, B., \& Duffy, R. (2012). Measuring meaningful work. Journal of Career Assessment, 20(3), 322-337. https://doi.org/10.1177/1069072711436160

Tajeddini, K., \& Trueman, M. (2008). The potential for innovativeness: A tale of the Swiss watch industry. Journal of Marketing Management, 24(1-2), 169-184. https://doi.org/10.1362/026725708x273984

Tierney, P., Farmer, S. M., \& Graen, G. B. (1999). An examination of leadership and employee creativity: The relevance of traits and relationships. Personnel Psychology, 52(3), 591-620.

https://doi.org/10.1111/j.1744-6570.1999.tb00173.x

Urdan, T., \& Maehr, M. (1995). Beyond a two-goal theory of motivation and achievement: A case for social goals. Review of Educational Research, 65(3), 213-243. https://doi.org/10.3102/00346543065003213

Vinarski-Peretz, H., \& Carmeli, A. (2011). Linking care felt to engagement in innovative work behaviors in the workplace: The mediating role of psychological conditions. Psychology of Aesthetics, Creativity, and the Arts, 5(1), 43-53. https://doi.org/10.1037/a0018241

Weitz, E., Vardi, Y., \& Setter, O. (2012). Spirituality and organizational misbehavior. Journal of Management, Spirituality \& Religion, 9(3), 255-281. https://doi.org/10.1080/14766086.2012.730782

Zhou, J., \& George, J. (2003). Awakening employee creativity: The role of leader emotional intelligence. The Leadership Quarterly, 14(4-5), 545-568. https://doi.org/10.1016/s1048-9843(03)00051-1

\section{Copyrights}

Copyright for this article is retained by the author(s), with first publication rights granted to the journal.

This is an open-access article distributed under the terms and conditions of the Creative Commons Attribution license (http://creativecommons.org/licenses/by/4.0/). 